\title{
Review of Renewable Energy Technologies in Zambian Households: Capacities and Barriers Affecting Successful Deployment
}

\author{
Priscilla Kachapulula-Mudenda ${ }^{1, *}$, Lilias Makashini ${ }^{2}$, Albert Malama ${ }^{3}$ and Henry Abanda 4 \\ 1 Department of Urban and Regional Planning, School of the Built Environment, The Copperbelt University, \\ P.O. Box 21692, Kitwe 10101, Zambia \\ 2 Department of Real Estate Studies, School of the Built Environment, The Copperbelt University, \\ P.O. Box 21692, Kitwe 10101, Zambia; lilias.masiba@cbu.ac.zm \\ 3 Department of Architecture, School of the Built Environment, The Copperbelt University, \\ P.O. Box 21692, Kitwe 10101, Zambia; albert.malama@cbu.ac.zm \\ 4 Department of Real Estate and Construction, Faculty of Technology, Design and Environment, \\ Oxford-Brookes University, Oxford OX3 0BP, UK; fabanda@brookes.ac.uk \\ * Correspondence: priscilla.kachapulula@gmail.com; Tel.: +260-212-290-855
}

Received: 2 March 2018; Accepted: 26 May 2018; Published: 30 May 2018

\begin{abstract}
Modern renewable energy has been hailed as one of the prerequisites for fostering green growth and the achievement of sustainable development. Despite efforts to promote the use of renewable energy in households, its adoption has remained fairly low, hence the need for an inquiry into household capabilities needed for the acquisition and adoption of renewable energy technologies. This paper reviews the requisite capacities of households for the adoption of renewable energy services and expounds on some of the barriers hampering renewable energy among households. It takes a desk research approach to analyse the capacities which should be possessed by Zambian households and possible barriers constraining the widespread deployment of renewable energy technologies. The findings reveal that there is a need for a broader, multidimensional understanding of access to renewable energy in order for deployment to be effective. Barriers to the successful adoption of clean energy technologies include underserved populations, policy inadequacies; an underexploited renewable energy sector and heavy reliance on a service-challenged hydro-power utility. Since most of the aforementioned challenges are institutional in nature, the paper concludes with a recommendation of a baseline assessment to understand knowledge, perceptions, attitudes and drivers for renewable energy technology adoption among households.
\end{abstract}

Keywords: renewable energy technologies; household capacities; access

\section{Introduction}

Renewable energy generated from hydro, solar, biomass, wind and geothermal resources offer immense prospects towards an eco-friendly and sustainable path to development. This is because technological advancements have paved the way for the conversion of these renewable resources into electricity, a valuable resource required to churn the wheels of social and economic development [1]. This is principally so for many energy-deficit developing countries, particularly when viewed against the backdrop of the potential benefits of renewable energy to other sectors of the economy. Broadly defined, Renewable Energy Technologies (RETs) are technologies providing electricity generated from renewable sources such as water, wind, solar, tidal waves and geothermal for activities such as household cooking, heating, space conditioning and water pumping [2]. From the households' point of view, transition to the use of renewable energy offers many benefits such as 
relieving people, particularly women and children of the time spent completing household activities manually without the aid of electricity [3], and the drudgery and health problems associated with the collection and use of woody fuels [4]. Other studies indicate positive outcomes such as livelihood improvement through productive uses of energy, sustainable urban planning and architecture, environmental sustainability and equitable energy service provision [5-9]. Apart from their potential to provide sustainable energy services, specific forms of RETs such as solar-powered systems also offer low-income households some form of financial autonomy over the energy service without fear of self-disconnection or similar sanctions from energy utilities. Yet, efforts aimed at inclusion and optimal exploitation of these energy sources remains below par. Closing the renewable energy gap in the country is a complex task which requires a thorough assessment of opportunities for expanded usage of green energy among Zambian households as well as understanding bottlenecks preventing its adoption. This paper reviews existing individual capacities needed for the adoption of renewable energy among households in Zambia and evaluates probable barriers which may have prevented successful adoption of RETs in households. A conceptual understanding of "renewable energy capacities" which has been adopted for this paper is households' ability to acquire and benefit from renewable energy services.

The problem of low usage of modern forms of energy and widespread dependence is one that is not peculiar to Zambia alone but is a developing country phenomenon [10]. Sub-Saharan Africa is said to be the most energy-poor region on the planet with electrification rates which are much lower than the rest of the developing world, as can be noted in Table 1 . About $80 \%$ of the population in this region still depend on traditional biomass, with the main indicator for this trend being the number of households where biomass is the main fuel for cooking [11]. It is interesting to note that biomass itself is a source of renewable energy if used efficiently and sustainably. However, it is often harvested unsustainably (woodlands, in particular) and used inefficiently [12], resulting in faster rates of forest depletion than regeneration. This source of energy has been overexploited in Zambia to levels where even the rainfall pattern has been affected. Marked degradation of forests and woodlands surrounding major cities such as Lusaka has been observed [9], which signifies a positive correlation between urban energy demand and excessive harvesting of wood for charcoal production.

Table 1. Electrification Rates Across Major Regions of the World [5].

\begin{tabular}{|c|c|c|c|c|}
\hline Region & $\begin{array}{l}\text { Population } \\
\text { Without Electricity } \\
\text { (Million Persons) }\end{array}$ & $\begin{array}{l}\text { Electrification } \\
\text { Rate }\end{array}$ & $\begin{array}{c}\text { Urban } \\
\text { Electrification } \\
\text { Rate }\end{array}$ & $\begin{array}{c}\text { Rural } \\
\text { Electrification } \\
\text { Rate }\end{array}$ \\
\hline Developing countries & 1283 & $76 \%$ & $91 \%$ & $64 \%$ \\
\hline Africa & 622 & $43 \%$ & $68 \%$ & $26 \%$ \\
\hline North Africa & 1 & $99 \%$ & $100 \%$ & $99 \%$ \\
\hline Sub-Saharan Africa & 621 & $32 \%$ & $59 \%$ & $16 \%$ \\
\hline Developing Asia & 620 & $83 \%$ & $95 \%$ & $74 \%$ \\
\hline China & 3 & $100 \%$ & $100 \%$ & $100 \%$ \\
\hline India & 304 & $75 \%$ & $94 \%$ & $67 \%$ \\
\hline Latin America & 23 & $95 \%$ & $99 \%$ & $82 \%$ \\
\hline Middle East & 18 & $92 \%$ & $98 \%$ & $78 \%$ \\
\hline Transition Economies \& OECD & 1 & $100 \%$ & $100 \%$ & $100 \%$ \\
\hline WORLD & 1285 & $82 \%$ & $94 \%$ & $68 \%$ \\
\hline
\end{tabular}

Even with the statistics presented in Table 1 above, vast differences in per capita household energy utilisation and overall electrification rates may be noted across Sub-Saharan countries. For instance, a few countries such as Cape Verde, Gabon, Mauritius and South Africa have made tremendous progress towards national electrification while the larger segment of the region is comprised of countries which have electrified barely half of their national populations [13]. Unfortunately, Zambia is one such country.

The development of the renewable energy sector offers many prospects of mitigating the current energy deficit faced by the country. Historically, renewable energy technologies in Zambia date back 
to the 1960s and 1970s when the first generation of hydro-power infrastructure was constructed to provide electricity to the mining areas and urban centres. Until the introduction of rural electrification programs, the provision of hydro-electric power has been concentrated along the rail lines (i.e., from southern to the Copperbelt province of Zambia) and in urban centres of other parts of the country. Over the years, the local energy sector has seen the addition of other RET innovations such as solar, geothermal, biomass and wind powered systems, whose presence and potential is as outlined below:

- Solar energy: The country has up to $3000 \mathrm{~h}$ of sunshine per annum. However, deployment of this form of energy in households has remained fairly low. Most installations are tilted towards social development projects, particularly health, education, institutional housing and water supply.

- Geothermal: 80 hot springs have been identified across the country, with 35 of these offering high potential for energy exploitation. Presently, only one miniature geothermal power plant at Kapisya hot springs has been exploited, whose current generation capacity is below its potential of 2 Mega-Watts (MW). The rest of the geothermal sites remain unexploited due to the high initial cost required for power generation. There is need for deliberate measures aimed at promoting Independent Power Providers (IPPs) who could either generate and supply electricity to the sole utility, Zambia Electricity Supply Corporation (ZESCO) or provide it to surrounding households for improved electrification rates and subsequent positive spillover effects.

- Biomass: Modern biomass energy sources in Zambia include but are not restricted to improved wood fuel, biogas digesters and biofuel. Several projects aimed at producing energy from biomass have been undertaken locally, although there is a dearth of statistics on the success rates of these efforts; resulting total energy output and; the number of households benefiting from these innovations.

- Wind: Prospects for large-scale investments in this form of energy are low due to low wind speeds (highest recorded speed is $10 \mathrm{~m}$ per second) which are unsuitable for power generation, but appropriate for domestic water-pumping and irrigation. A wind atlas would be helpful in determining the full potential of wind energy in Zambia.

Despite the aforementioned RET potential, empirical evidence presented in literature depicts Zambia as undersupplied with modern renewable energy with the majority of households still reliant on traditional biomass [charcoal and firewood] [10,14]. This form of energy accounts for about $80 \%$ of total local energy requirements, translating to $284 \mathrm{PJ}$ mainly for household thermal comfort and cooking purposes [15]. Not only are these fuels noted for their insufficiency to meet the full range of household energy needs but also their adverse impacts ranging from environmental degradation to domestic nuisances such as indoor air pollution [10], burns, poisonings and scalds [16,17]. Currently, the electrification rate for Zambia is about 22\% [15]. Notwithstanding, national averages such as this tend to obscure intranational electrification levels and the actual state of energy poverty, especially in rural areas [13]. As shown in Figure 1, the majority of the national population receives marginal opportunities for the adoption of RETs. 


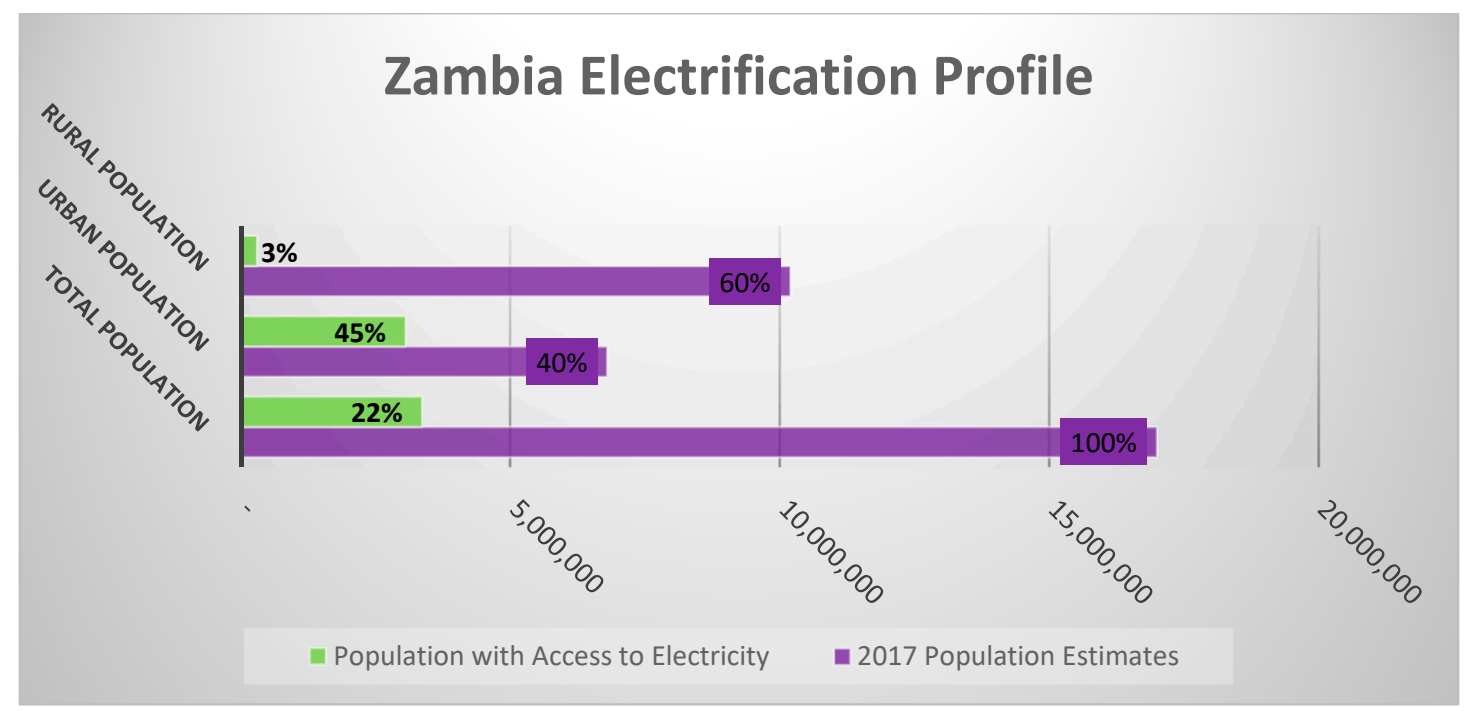

Figure 1. Statistics used above were extracted from the Renewables Readiness Country Assessment [15] and the local statistical bureau [18].

The persistent use of traditional biomass and its association to energy poverty has prompted scholars to offer analytical perspectives comparing high-income, energy-efficient sections of society with low-income, traditional biomass-dependent ones. One such analytical school of thought is the theory of the Energy Ladder. In a nutshell, the theory states that households undergo an energy transition process of adopting cleaner, modern forms of energy as their socio-economic statuses improve [19-22]. Ceteris paribus, energy use patterns in households are supposed to reflect Zambia's recent change of status as a lower middle-income country with considerable levels of deployment of RETs in households. Yet, a study undertaken by Tembo et al. [21] of low-, middle- and high-income households in Lusaka, the capital city of Zambia reveals that even among electrified residences, more households use a combination of renewable energy and traditional biomass (mainly charcoal) than those which depend on renewable energy alone. This energy consumption pattern was observed across all income brackets. They conclude that the energy use trend in Zambia is that of energy-stacking rather than energy-switching to renewable forms of energy. This finding has important implications on:

- Reliability of hydro-electric renewable energy for use in households.

- Probable socio-cultural influence on household energy habits (traditional biomass has been used among Zambian households whether rural or urban since time immemorial [23]).

- Drivers and deterrents of RET adoption among households.

- Diversity of the RET market in Zambia.

Increased interest in RETs (specifically, hydro, solar, wind and biomass) in Zambia comes at a time when the country has just emerged from a phase of considerable power-rationing between 2015 and the first quarter of 2017, with load-shedding sessions lasting as long as $8 \mathrm{~h}$ per day [1]. This, in turn, perpetuated the use of charcoal as an alternative source of energy particularly in urban centres. The levels of modern energy usage as illustrated in Figure 1 indicate that the energy access situation in Zambia is one that needs attention and effective intervention in order for the country to achieve accelerated levels of social and economic development. Empirical evidence shows that there is a strong linkage between access to modern energy and development focal areas such as education, food security, health, poverty reduction, gender equality and climate change [2-4]. Assessing RET access is essential in understanding the reasons why RET deployment in households in Zambia remains considerably low. 


\section{RET Capacities and Barriers Affecting Successful Deployment in Zambia}

\subsection{Households' Requisite Capacities for the Acquisition of Renewable Energy}

\subsubsection{Access}

Households' ability to acquire cleaner energy-carriers is an essential component of improving the wellbeing of underprivileged individuals and communities in developing countries [8]. Ruppel and Althusmann [5] demonstrate a correlation between a nation's poverty levels and access to electricity. This is supported by Karekezi et al. [9] who show the high levels of poverty in comparison with the levels of electrified households. Prior perspectives on access to energy for the poor focused on policy reforms to provision of infrastructure which would then ensure the connection of excluded areas to the electricity grid, thereby ensuring provision of modern energy for all. Brew-Hammond [24], in quoting Ranjat and Sullivan, describes access as the households' ability to obtain the energy-service due to availability and ability to pay upfront. However, Avila el al [14] report that access to modern energy should be viewed beyond the physical acquisition of cleaner energy-carriers to encompass other socioeconomic factors or dynamics which determine households' ability to obtain and maintain renewable-energy usage over the long-term. These factors are further discussed in Figure 2 below:

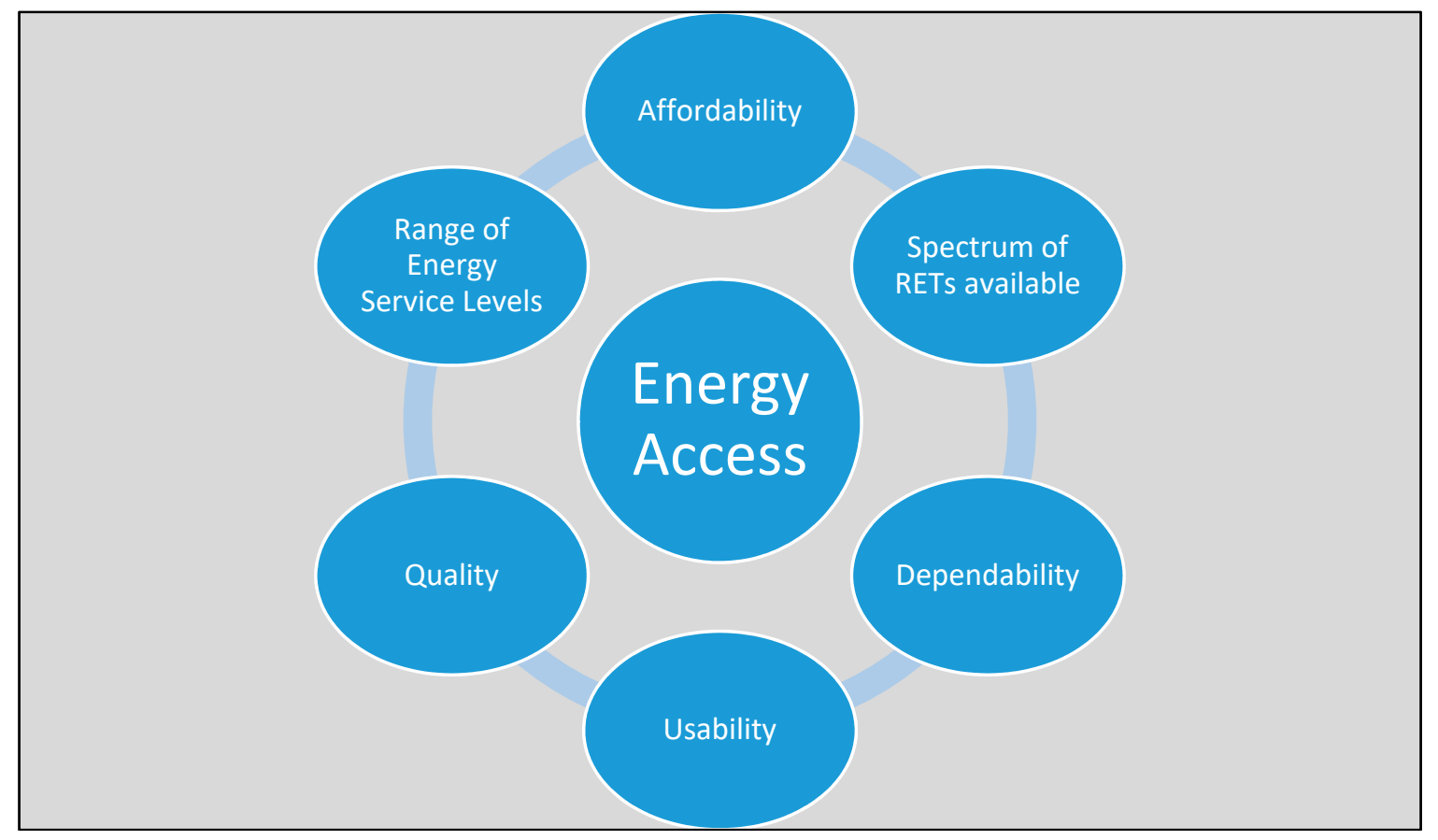

Figure 2. Adapted from Avila et al. [14], this graphical representation demonstrates the various facets of renewable energy access.

\subsubsection{Range of Energy Service Levels}

The user should have the liberty to choose from the range of renewable energy technologies available for use in a given locality. In Zambia, the main national electricity grid is powered by hydro technology but the electrification levels are low. Hence many people cannot access it. Alternative sources include biomass, solar and wind technologies, which come in the form of solar geysers, solar light fittings, improved cook stoves using wood fuel and gas [25-27]. The Zambian Government through the Rural Electrification Master Plan (REMP) and the help of the Japanese Government has embarked on a project to increase rural energy access through the extension of the national grid, construction of mini-hydro power stations and the installation of solar home systems [28]. 


\subsubsection{Dependability and Quality}

Available modes of energy ought to have a certain level of reliability in order to guarantee sustainable use from the households' point of view. This is because, as Yadoo and Cruickshank [29] suggest, the unreliability and shortage of grid power in many areas hampers economic development severely. In a Solar Homes Systems Project conducted in the Eastern Province of Zambia it was discovered that people were less willing to pay if the systems were not delivering the advocated services. This Solar Homes project was established in the year 2000 as a pilot study to determine the appropriateness of use of energy utility companies in the rural electrification strategy by the Zambian government, through the support of the donor agency, SIDA. It was undertaken in a town called Nyimba, located in the Eastern Province of Zambia. Furthermore, those businesses offering good quality components were more successful than those supplying low-cost unreliable systems [30]. Also, generating energy from renewable resources guards against the fluctuations of fossil fuel prices and thereby improves the energy security. Renewable energy can be depended on to improve the energy situation in a country like Zambia because of its proven potential. According to a Zambia- China renewable energy technology project launched in 2014, solar radiation levels in Zambia are amongst the highest in the world with annual averages of about $7100 \mathrm{MJ} / \mathrm{m}^{2}$ [30]. This has seen a number of pilot solar energy projects being implemented across the country with the support of the public and donors agencies. Avila et al. [14] discusses the various tiers which households undergo as they improve on the quality of energy required for cooking, lighting and space-conditioning. They assert that, the higher the tier, the more modern the type of energy in use in a particular household.

\subsubsection{Affordability}

RETs are capital intensive, requiring significant upfront costs. With the majority of the rural poor not electrified and in far flung and often inaccessible areas, connection to the national electricity grid is economically feasible, but requires high capital costs. Hence new and innovative technologies are required and must be cost effective [31]. Literature documented of other developing countries indicates that services from RETs are unaffordable to the majority of the poor in rural and peri-urban areas [32]. However, RETs are the cheaper solution in off-grid areas. According to Glemarec [33], rapid technological innovations and increased commercialisation have resulted in a decrease in manufacturing costs, hence lower prices for RETs and more creative accessibility. This is supported by the Solar Homes Systems Project in Eastern Province of Zambia where the households pay only for battery charging and maintenance of the technology or what is called 'fee for service'. The households do not pay for purchasing the systems but only pay for its use and maintenance. This has made the system more affordable to the households. In proposing solutions to the affordability component of access to clean energy, the International Renewable Energy Agency [15] recommends targeted subsidies and deferred payments schemes. These can be applied to individual households systems or mini-grids as this could increase access to electricity services in rural Zambia.

\subsubsection{Usability}

For RETs to be adopted by households, they need to meet the needs of the households adequately and efficiently. Complicated technology often is received with resistance while simple technologies usually receive acclaim for ease of adaptability and ability to positively influence livelihoods. For instance, outcomes of the solar home systems project undertaken in Eastern Province (Zambia) reveal that households admitted to having an improved standard of living owing to the transition to solar energy technology They were able to acquire televisions and video players powered by the solar systems; the improved quality of lighting also enabled studying for longer hours and a broader level of domestic services [34]. 


\subsubsection{Availability of RETS}

RETs provide attractive environmentally sound technology options for Africa's electricity industry. Common RET options for providing energy especially in rural areas include wind energy primarily for pumping water; biomass for cooking, solar Photovoltaic (PV) systems which convert sunlight into electricity and small-scale hydropower plants which generate electricity [35]. At household level, energy is required for lighting, cooking, heating of water and space conditioning, as well as powering appliances [9]. RETs in Zambia available on the market include solar water geysers, solar lights, solar cookers, improved cook stoves, hot bags and water pumps [11]. The SADC Renewable Energy and Energy Efficiency Status Report of 2015 [11] shows that although the SADC region is faced with challenges such as energy access, many of the country members are making strides in the adoption of RETs. For instance, the Report states that the Democratic Republic of Congo, Lesotho, Malawi, Mozambique, Zambia and Zimbabwe already make significant contribution towards the adoption of renewable energy. In addition, a SNV Biofuels for Lighting Project, launched in 2013, produced 676 litres of jatropha oil, supporting the production of 760 jatropha lamps in 2013 alone. The project further included the production of 4325 improved cook stoves [11].

\subsection{Factors Hampering Successful Adoption of Renewable Energy in Zambian Households}

\subsubsection{Underexploited Renewable Energy Sector}

Zambia is endowed with renewable energy resources which are being exploited only to a limited degree. Much of the renewable energy production is still biased towards hydro-electric power generation. What's worse, only $33 \%$ of the total electricity production services the residential sector despite an ever-increasing demand for electrification of more households [36]. Renewable energy under-exploitation may be one of the key reasons why its usage among households has been consistently low. Table 2 below illustrates renewable energy potential in the country. Apart from statistics which indicate that the current utilisation of hydro-powered renewable energy is $2225 \mathrm{MW}$, data on utilisation levels of other non-hydro powered RETs is not available.

Table 2. Information contained in the Table above was mostly extracted from the Renewable Readiness Country Assessment. Other sources are as indicated.

\begin{tabular}{|c|c|c|}
\hline Renewable Energy & Resource Availability & Potential Output \\
\hline Hydro & $\begin{array}{l}\text { Multiple mini and major sites across the cross; country possesses over } 40 \% \\
\text { of water resources in SADC region [37] }\end{array}$ & $6000 \mathrm{MW}$ \\
\hline Biomass & 2.15 million tonnes [36] & $498 \mathrm{MW}$ \\
\hline Wind & Average $-3 \mathrm{~m} / \mathrm{s}$ at $10 \mathrm{~m}$ height; hotspots in Northern and Eastern regions. & Not quantified \\
\hline Geothermal & 80 hot-springs; 35 viable [38]. & Not quantified \\
\hline Solar & $5.5 \mathrm{KWh} / \mathrm{m}^{2} /$ day; Approx. 3000 sunshine hours per annum & Not quantified \\
\hline
\end{tabular}

\subsubsection{Infrastructural Pitfalls}

Ahlborg et al. [39] attribute low levels of modern energy in households to infrastructural underdevelopment of the energy sector. They argue that this state of underdevelopment is broadly marked by features such as low levels of access to the national grid, inadequate generation capacity, and weak generation, transmission and distribution infrastructure. Although macro in nature, these factors have a bearing on the levels of access to renewable energy by households and will be individually discussed.

Firstly, although Zambia is rapidly urbanising, more than half of the population is still rural. The dispersed nature of rural settlements in Zambia implies that substantial amounts need to be expended towards infrastructure necessary for grid connection in remote areas [40], particularly if the rural areas have low population densities and difficult terrain [41]. According to the Economical Distance Limit analysis, nearly all renewable energy technologies have a certain potential for integration into the grid extension system in remote areas of the country, under specific conditions 
such as distance and the population being served. However, for such technologies to be integrated, significant levels of financial commitment are required [15]. This is of particular concern for a fiscally deficit country like Zambia. While efforts by the local Rural Electrification Authority (REA) to enhance wind energy production in rural areas may be commended [41], infrastructural weaknesses associated with wind energy systems may have restricted widespread adoption of this particular form of renewable energy (see Table 3). Also, until recently, REA's renewable energy development efforts were inclined towards grid extension. These efforts were frustrated by technical and financial constraints, which has resulted in slowed electrification of rural households [15]. Since energy is an essential service required to satisfy cooking and heating needs on a daily basis, rural households continue to depend on traditional biomass to meet energy needs until off-grid efforts such as solar home installations and other stand-alone technologies materialise.

Table 3. Information adapted from a RET module [42] available online.

\begin{tabular}{ll}
\hline \multicolumn{1}{c}{ Strengths } & \multicolumn{1}{c}{ Weaknesses } \\
\hline $\begin{array}{l}\text { Technology is moderately simple and robust with lifetimes of } \\
\text { over 15 years without major additional investment }\end{array}$ & $\begin{array}{l}\text { Site-specific technology (success likely only in few parts } \\
\text { of the country) } \\
\text { Automatic operation with low maintenance requirements } \\
\text { (no fuel required) }\end{array}$ \\
$\begin{array}{l}\text { Low environmental impact } \\
\text { Technology can be adapted for part or complete manufacture power produced, therefore storage/backup required. } \\
\text { in developing countries }\end{array}$ & $\begin{array}{l}\text { High capital/initial investment costs can hinder adoption } \\
\text { (especially in developing countries) }\end{array}$ \\
\hline
\end{tabular}

Secondly, bearing Zambia's heavy reliance on hydro-generated electricity in mind, not all of the installed power generation capacity is operational. This is due to challenges such as obsolete equipment and maintenance problems [43]. There has been an acknowledgement about the lack of investment in generation capacity over the past two to three decades [36] which has resulted in this poor infrastructural performance. Weak generation, transmission and distribution infrastructure imply that less households are serviced than would be the case if the hydro-powered energy sub-sector was optimally functioning. Avila [14] proposes a regional integration approach to expanding RETs where countries with a comparative advantage in a specific form of renewable energy contribute to the regional grid, thus increasing the overall power generation capacity and consequent number of households being serviced.

\subsubsection{Energy Poverty}

A study undertaken by Imasiku [44] reveals a well-established retail market for affordable traditional biomass (specifically, charcoal) commonly used by households regardless of socioeconomic status. The current situation of heavy dependence on traditional biomass by local households is, to a great extent, symptomatic of energy poverty and failure to afford modern fuels [13]. It is for this reason that energy provision has had some political nuances associated with it due to Government's influence on energy tariff structures to promote equity [36]. Poor people are likely to face challenges associated with the high upfront cost of acquiring RETs, especially when compared with the low cost of charcoal (which is usually packaged in as varied quantities as possible for even the most energy-poor households to afford) and requisite braziers. In some instances, a household dependent on traditional biomass may be able to afford the recurring cost of a cleaner source of energy such as Liquefied Petroleum Gas (LPG) but fail to afford the obligatory LPG stove and gas cylinder, thus eliminating the likelihood of switching fuels [8]. Although the latest global stand-point indicates that the costs of renewable energy which can be adopted by households are plummeting due to scale economies and technological improvements [6], affordability of RETs is yet to be empirically validated on the local level. 


\subsubsection{Policy Inadequacies}

Zambia's policy direction with regard to RETs is guided by the new National Energy Policy of 2008 [23], which was an outcome of consultative reviews of preceding policy tools. With respect to renewable energy, the policy tool seeks to address barriers to the use of RETs. However, in its present state, the policy emphasises grid-connected hydropower at the expense of other renewable energy technologies, although other Government development guidelines such as the National Development Plans (Transitional: 2002-2005; Fifth: 2006-2010 and; Sixth: 2011-2015) and the Vision 2030 mention the importance of incorporating other RETs to meet Zambia's growing energy needs [15]. The Renewable Energy Strategy of 2010, a follow-up implementation plan to the National Energy Policy offers a broader renewable energy perspective, with specific targets for electricity generation using various RETs. Unfortunately, the Strategy has not been adopted for implementation [15]. A revival of this and other useful strategies could go a long way in diversifying renewable energy away from hydro-powered electricity to having a mix of technologies which households could adopt. Additionally, the World Bank [2] recommends:

- Long-term commitment by the Government towards accelerated RET access as opposed to short-term, piecemeal approaches.

- Creation of regulations and institutions whose principle aim is to facilitate in the expansion of new forms of renewable energy.

- Either promotion of innovative income-earning activities to identified households in order for them to afford access or financial support to IPPs to reduce the high upfront costs of developing a model to supply energy to unserved populations.

\subsubsection{Low Levels of Awareness}

A low level of awareness about the benefits, functional characteristics and efficiency of renewable energy technologies available for use by households is another factor which may have prevented successful adoption [42] of RETs in Zambia. Mwape [23] affirms that the policies, incentives and benefits associated with RETs in Zambia have not been effectively communicated to energy users to the extent that they would make informed and deliberate decisions to transition to the use of renewable energy. Also, consider that renewable energy technology is ever improving, resulting in better and more efficient products over time. Usage of improved RETs would partly depend on how well-informed a potential household decision-maker is when choosing modes of energy for domestic use. Therefore, when faced with inadequate information, users of old, less-efficient products may still hold notions about inadequacies associated with renewable energy technologies. She further reveals that the low levels of awareness are attributed to inappropriate modes of communication (especially in rural areas where the population may not have access certain forms of media) and local agencies' failure to accommodate household energy users with low levels of literacy (English is the official language in Zambia and the main language used during energy campaigns in media). It is said that the poor knowledge base and misconceptions about renewable energy technologies are widespread among potential household users, thus limiting the adoption and subsequent usage of RETs [42].

\subsubsection{Upward Adjustment in Household Tariffs}

As an attempt to mitigate fiscal deficits, the country's sole electricity utility recently implemented long-standing tariff adjustments in a bid to make the energy service as cost-reflective as possible [15,36]. Tariffs were adjusted upward by about $75 \%$ over a period of 5 months in 2017. This increment in electricity tariffs may have served as a disincentive to electricity usage among urban households, especially in an environment where there is dominance of hydro-electricity whose service provision is laden with challenges, and weak advocacy towards the adoption of alternative RETs [18]. 


\subsubsection{Planned Service, Unplanned Settlements}

Although the energy access deficit in Zambia is largely rural, projections by the local populations bureau indicates that by the year 2030, the country's population will stand at over 23.5 million, with about $50 \%$ of this population residing in urban areas [18]. However, the typical urban phenomenon in Zambia is that of the densely populated unplanned settlements which make up the majority of households in urban areas, where energy services are accessed with much difficulty. Although the local energy utility company has endeavoured to provide electricity to some informal settlements, not all slums in the urban centres of Zambia have been electrified. This is partly due to the fact that the legal framework allows for electrification of only informal settlements which have been earmarked for upgrading and excludes other slums with an illegal status. The challenge is how to make institutionalised renewable energy technologies such as hydro-powered energy available to these unserved masses. Energy access challenges in slums are noted both in terms of the quality of energy carriers used as well as the RETs available for use.

\subsubsection{Weak Management of the Electricity Sub-Sector}

Karekezi [9] also reports that the renewable energy section energy sector in most Sub-Saharan countries such as Zambia is characterised by management difficulties such as high power-supply system losses due to unmetered and unbilled household electricity consumption. The aforementioned energy losses are in part due to electricity thefts and non-payment of bills on the part of some unscrupulous households, which result in a decline in the quality of energy systems and slowed grid expansion to the subserviced urban and rural areas [45].

The UNDP [31] has better summarised the barriers to successful deployment in Table 4 below:

Table 4. Barriers to successful deployment of RETs in Zambia.

\begin{tabular}{l}
\hline Policy and Regulatory Hindrances \\
\hline Small electricity producers have difficulties connecting to the grid network. Inadequate incentives for \\
renewable energy development \\
Lack of standardised Power Purchase Agreements deters potential investors in power generation. \\
Lack of fair competition in the energy sector to attract Independent Power Producers in the energy sector. \\
Incomplete implementation of Zambia's policy/legal and institutional framework to promote renewable \\
energy production and diffusion \\
\hline Institutional Barriers \\
\hline Limited capacity to evaluate technical, financial and economic proposals as well as, market development, \\
and marketing of renewable energy projects \\
Spatial distribution of suppliers' limit access to renewable energy equipment \\
Limited coordination among ministries \\
Open access regime incomplete \\
\hline Technical Limitations \\
\hline Limited technical capacity to design, install, operate, manage and maintain renewable energy systems \\
Limited or non-existent standards for energy performance, manufacture, installation and maintenance \\
Lack of local manufacturing and/or assembly of renewable energy technology components \\
\hline Human Resources and Awareness Challenges \\
\hline Limited availability and access to existing information on renewable energy resources and potential \\
Limited public awareness of renewable technologies \\
Availability of resources for mini-hydro is site specific, requiring detailed analysis of local conditions \\
\hline Financial Barriers \\
\hline The Rural Electrification is Fund ineffective \\
High capital cost of renewable energy products \\
Lack of economies of scale due to dispersed market \\
Lack of bulk procurement limited due to market size \\
\hline
\end{tabular}




\section{Discussion}

A diversified renewable energy sector is a prerequisite for the widespread adoption of RETs among Zambian households. Inadequate data on RET deployment at household level implies that actual household RET usage (in particular, non-hydro powered technologies) is unknown. There is, therefore, need to engage in deliberate and extensive data-collection via such public organs as Central Statistics Office (CSO) to capture household renewable energy usage patterns for policy-makers, public and independent power providers as well as other actors in the renewable energy sector. To this effect, this Paper proposes a countrywide baseline study to collect data on household RET usage, including knowledge, perceptions, and attitudes towards household RET adoption. Even though the costs of acquiring RETs are reported to have declined in the recent past, there is a need to assess whether most Zambian households can now afford to adopt RETs for usage in the long-term. The affordability variable needs to be tested against the backdrop of varied incomes and other socio-economic considerations. A preferable future outcome would be a national database which consistently updates residential renewable energy development. As earlier noted, the continued use of traditional biomass by high-income households through energy-stacking patterns could imply a well-established market for charcoal as compared with non-hydro powered RETs. It could also imply limited RET options available for use, even among the affluent in society. Noteworthy is the country's effort to scale up on RET deployment as stated in various policy instruments. However, what seems to affect progress is poor funding. Prioritisation of resources towards viable RET options would go a long way in promoting the diversification of RETs available for adoption by households in Zambia. Future policy directions should also aim at encouraging independent power producers to supplement Government's effort to provide renewable energy to households through incentives and subsidies. Although literature seems to document more efforts towards rural electrification, the urban poor need to be given as much attention, especially in view of possibilities for livelihood improvement through micro-enterprises they would engage in if they had access to modern energy. Additionally, it is imperative that regulatory and institutional measures be taken when considering the fate of the informal settlers' energy problems.

\section{Materials and Methods}

This paper used a desk research approach to analyse capacities which should be possessed by Zambian households and possible barriers constraining widespread deployment of RETs. Literature, which included journal articles, sector reports (both local and international) and books, was reviewed for purposes of summarising and interpreting insightful information on renewable energy capacities and barriers affecting RET usage. Data was subsequently collated in order to extract current information concerning the aforementioned variables and finally synthesised to form a comprehensive discussion. For a more focused discourse, the following research objectives were formulated:

1. Review households' requisite capacities for the successful acquisition of renewable energy.

2. Carry out an investigation of the factors hampering successful adoption of renewable energy in Zambian households.

\section{Conclusions}

RETs offer viable opportunities for sustainable energy provision to households in Zambia. Despite efforts to promote the use of renewable energy in households, its adoption has remained fairly low, hence the need to make an inquiry into households' capabilities needed for the acquisition and adoption of renewable energy technologies. This has implications for the reliability of hydro-electric renewable energy for use in households; possible socio-cultural influence on household energy habits; drivers and deterrents of RET adoption among households, and; diversity of the RET market in Zambia. This paper reviewed the requisite capacities of households for the adoption of renewable energy services and discussed some of the barriers hampering renewable energy among 
households. It utilised a desktop research approach to analyse capacities which should be possessed by Zambian households and possible barriers constraining widespread deployment of renewable energy technologies. Findings reveal that there is a need for a broader, multidimensional understanding of access to renewable energy in order for deployment to be effective. Barriers to successful adoption of clean energy technologies include underserved populations, policy inadequacies; underexploited renewable energy sector and heavy reliance on a service-challenged hydro-power utility. Since most of the aforementioned challenges are institutional in nature, the paper recommends a baseline assessment to understand knowledge, perceptions, attitudes and drivers for renewable energy technology adoption among households.

Author Contributions: All authors contributed equally to the development of this Review Paper.

Conflicts of Interest: The authors declare no conflict of interest.

\section{References}

1. Eltrop, L. Renewable Energy: Resources and Technologies. In Glances at Renewable and Sustainable Energy Principles, Approaches and Methodologies for Ambiguous Bechmark; Jenssen, T., Ed.; Springer: Berlin, Germany, 2013; Volume VII, p. 105, ISBN 978-1-4471-5136-4.

2. U.N. Conference on Trade and Development. Renewable Energy Technologies for Rural Development. Available online: http:/ / unctad.org/en/Docs/dtlstict20094_en.pdf (accessed on 20 February 2018).

3. Thiam, D.R. Renewable energy, poverty alleviation and developing nations: Evidence from Senegal. J. Energy S. Afr. 2011, 22, 23-34.

4. Behl, R.K.; Chhibar, R.N.; Jain, S.; Bahl, V.P.; El Bassam, N. Renewable Energy Sources and Their Applications; Agrobios (International): Jodhpur, India, 2013; ISBN 978-93-81191-01-9.

5. Ruppel, O.C.; Althusmann, B. Perspectives on Energy Security and Renewable Energies in Sub-Saharan Africa Perspectives on Energy Security and Renewable Energies in Sub-Saharan Africa, 2nd ed.; Macmillan Education Namibia: Windhoek, Republic of Namibia, 2015; ISBN 9991639101.

6. World Bank. State of Electricity Access Report; World Bank: Washington, DC, USA, 2017.

7. Mahdavinejad, M.; Karimi, M. Challenges and Opportunities Regarding Adoption of Clean Energy Technology in Developing Countries, in Case of Iran. IJSGCE 2012, 2, 283-288. [CrossRef]

8. Sovacool, B.K. Energy, Poverty, and Development; Routledge: Abingdon-on-Thames, UK, 2014.

9. Karekezi, S.; Kithyoma, W. Renewable energy development. In Proceedings of the Workshop for African Energy Experts on Operationalizing the NEPAD Energy Initiative, Dakar, Senegal, 2-4 June 2003.

10. UN-DESA. Sustainable Energy Consumption in Africa; UN-DESA Report; UN-DESA: New York, NY, USA, 2004.

11. REN21. SADC Renewable Energy and Energy Efficiency; Status Report; REN21: Paris, France, 2015.

12. OECD/IEA. World Energy Outlook: Energy for Cooking in Developing Countries; OECD/IEA: Paris, France, 2006; pp. 419-445.

13. James, M. The Energy Challenge in Sub-Saharan Africa: A Guide for Advocates and Policy Makers: Part 2: Addressing Energy Poverty. 2017. Available online: https://www.oxfamamerica.org/static/media/files/ oxfam-RAEL-energySSA-pt2.pdf (accessed on 22 December 2017).

14. Avila, N.; Carvallo, J.P.; Shaw, B.; Kammen, D.M. The Energy Challenge in Sub-Saharan Africa: A Guide for Advocates and Policy Makers Part 1: Generating Energy for Sustainable and Equitable Development. 2017. Available online: https://www.oxfamamerica.org/static/media/files/oxfam-RAEL-energySSA-pt1.pdf (accessed on 22 December 2017).

15. International Renewable Energy Agency. Renewables Readiness Assesment-Zambia; IRENA: Masdar, Abu Dhabi, UAE, 2013. Available online: http://www.irena.org/documentdownloads/publications/ rra_zambia.pdf (accessed on 29 May 2018).

16. Kimemia, D.; Vermaak, C.; Pachauri, S.; Rhodes, B. Burns, scalds and poisonings from household energy use in South Africa: Are the energy poor at greater risk? Energy Sustain. Dev. 2014, 18, 1-8. [CrossRef]

17. Howells, M.I.; Alfstad, T.; Victor, D.G.; Goldstein, G.; Remme, U. A model of household energy services in a low-income rural African village. Energy Policy 2005, 33, 1833-1851. [CrossRef]

18. Central Statistical Office. 2010 Census of Population and Housing: Population Summary Report; Central Statistical Office: Lusaka, Zambia, 2012; p. 142. 
19. Hanna, B.R.; Oliva, P. Moving up the Energy Ladder: The Effect of an Increase in Economic Well-Being on the Fuel Consumption Choices of the Poor in India. Am. Econ. Rev. 2015, 105, 242-246. [CrossRef]

20. Der Horst, G.H.; Hovorka, A.J. Reassessing the 'energy ladder': Household energy use in Maun, Botswana. Energy Policy 2008, 36, 3333-3344. [CrossRef]

21. Tembo, T.S.; Mulenga, P.B.; Sitko, N. Cooking Fuel Choice in Urban Zambia: Implications on Forest Cover; Working Paper No. 94; Indaba Agricultural Policy Research Institute (IAPRI): Lusaka, Zambia, 2015.

22. Toole, R. The Energy Ladder: A Valid Model for Household Fuel Transitions in Sub-Saharan Africa? Master's Thesis, Urban and Environmental Policy and Planning, Tufts University, Medford, MA, USA, 2015.

23. Mwape, S.C. The Struggle against the Unsustainable Usage of Woodfuel through the Promotion of Alternative Energy Sources in Peri-Urban Areas. Master's Thesis, The University of Zambia, Lusaka, Zambia, 2015.

24. Brew-Hammond, A. Energy access in Africa: Challenges ahead. Energy Policy 2010, 38, 2291-2301. [CrossRef]

25. Sovacool, A.K. Expanding renewable energy access with pro-poor public private partnerships in the developing world. Energy Strategy Rev. 2013, 1, 181-192. [CrossRef]

26. Energy Regulation Board. Energy Sector Report-Zambia. 2014. Available online: http://www.erb.org.zm/ reports/EnergySectorReport2014.pdf (accessed on 23 February 2018).

27. The National Energy Policy-Zambia. 2008. Available online: https://static1.squarespace.com/static/ 58c95e0c5016e18d705d710a/t/58ee21f0ebbd1a718d26a06d/1492001282630/National+Energy+Policy+ 2008.pdf (accessed on 27 February 2018).

28. Diecker, J.; Scott, A.; Wheeldon, S. Accelerating Access to Electricity in Africa with Off_Grid Solar Off; ODI: Lusaka, Zambia, 2016.

29. Yadoo, A.; Cruickshank, H. The role for low carbon electrification technologies in poverty reduction and climate change strategies: A focus on renewable energy mini-grids with case studies in Nepal, Peru and Kenya. Energy Policy 2012, 42, 591-602. [CrossRef]

30. Gustavsson, M.; Ellega, A. The impact of solar home systems on rural livelihoods. Experiences from the Nyimba Energy Service Company in Zambia. Renew. Energy 2004, 29, 1059-1072. [CrossRef]

31. United Nations Development Programme. China-Zambia South-South Cooperation on Renewable Energy Technology Transfer; United Nations Development Programme: New York, NY, USA, 2014.

32. Surendra, K.C.; Kumar, S.; Shrestha, P.; Lamsal, B. Current status of renewable energy in Nepal: Opportunities and challenges. Renew. Sustain. Energy Rev. 2011, 15, 4107-4117.

33. Glemarec, Y. Financing off-grid sustainable energy access for the poor. Energy Policy 2012, 47, 87-93. [CrossRef]

34. Gustavsson, M. Educational benefits from solar technology-Access to solar electric services and changes in children's study routines, experiences from eastern province Zambia. Energy Policy 2007, 35, 1292-1299. [CrossRef]

35. Watson, J. Renewable Energy Technologies for Rural Development; UNCTAD Current Studies on Science, Technology and Innovation; UNCTAD: Geneva, Switzerland, 2010.

36. Policy Report on the Electricity Sector in Zambia. 9 October 2016. Available online: http://www. freedomtocreate.com/ftc/wp-content/uploads/2017/06/FTC_Electricity_Sector_in_Zambia.pdf (accessed on 10 January 2018).

37. Banda, D.E. Shared Water Resources in the SADC. Master's Thesis, University of Nairobi, Nairobi, Kenya, 2013.

38. Energy Sector Profile-Zambia. September 2014. Available online: http://www.zda.org.zm/?q=download/ file/fid/55 (accessed on 18 January 2018).

39. Ahlborg, H.; Boräng, F.; Jagers, S.C.; Söderholm, P. Provision of electricity to African households: The importance of democracy and institutional quality. Energy Policy 2015, 87, 125-135. [CrossRef]

40. Mohammed, Y.S.; Mustafa, M.W.; Bashir, N. Status of renewable energy consumption and developmental challenges in Sub-Sahara Africa. Renew. Sustain. Energy Rev. 2013, 27, 453-463. [CrossRef]

41. Musonda, G. Status of Rural Electrification in Zambia. 11 April 2017. Lusaka. Available online: http:// eepafrica.org/wp-content/uploads/Presentation-Status-of-Rural-Electrification-In-Zambia-KEF.pdf (accessed on 20 February 2018).

42. SERPA. Sustainable Energy Regulation Policy for Africa. Module 7. Available online: https:/ / www.unido. org/sites/default/files/2009-02/Module7_0.pdf (accessed on 21 February 2018).

43. Eberhard, A.A.; Shkaratan, M.; Rosnes, O. Africa's Power Infrastructure: Investment, Integration, Efficiency; World Bank: Washington, DC, USA, 2011; pp. 1-352, ISBN 978-0-8213-8455-8. 
44. Imasiku, Y. Challenges Affecting the use of Green Energy in Selected Communities on the Copperbelt Province of Zambia. Bachelor's Thesis, Copperbelt University, Kitwe, Zambia, 2016.

45. Winther, T. Energy for Sustainable Development Electricity theft as a relational issue: A comparative look at Zanzibar, Tanzania, and the Sunderban Islands, India. Energy Sustain. Dev. 2012, 16, 111-119. [CrossRef] 